\title{
Metasomatic studies in Bulgaria - an overview
}

\author{
Angel Kunov \\ Geological Institute "Strashimir Dimitrov", Bulgarian Academy of Sciences, Acad. G. Bonchev Str., Bl. 24, 1113 Sofia, \\ Bulgaria; e-mail: angelkunov@abv.bg
}

(Accepted in revised form: October 2017)

\begin{abstract}
This brief overview presents the study of metasomatic processes and rocks in Bulgaria. The very beginning of metasomatic studies coincides with the first steps of Bulgarian geology, with the discovery and description of minerals that are basic for altered rocks. Subsequently, the processes of spilitization and uralitization, the formation of fluorite-silicated rocks during intensive metasomatic alteration of marbles, were characterized. Around and after 1950, the increase in mapping and geological and mining activities created prerequisites for rapid development of the study of metasomatic processes, and especially of wall-rock alterations as their particular cases. Many new data filled in the pages of geological reports and the first dissertations. This was also the time of characterization of new metasomatic processes and metasomatic products for Bulgaria: potassium feldspatization and granitization, propylites and secondary quartzites, etc.
\end{abstract}

Nowadays, the following metasomatic families have been established in Bulgaria: skarn, quartz-feldspar metasomatic rocks, greisen, beresite, secondary (hydrothermal) quartzite, propylite, argillisite, aceite, quartzsericite and quartz-adularia-sericite. The products of potassium feldspatization and granitization, as well as rodingites, can also be included.

The Geological Institute "Strashimir Dimitrov" (Bulgarian Academy of Sciences) is the cradle of the metasomatic doctrine in Bulgaria. Taking the best of world science, the metasomatic direction in our country has created its own image. Collaboration with prominent specialists from leading countries have helped Bulgarian metasomatists grow and show their knowledge at a number of geological forums in Bulgaria and abroad, as well as in theoretical and practical aspects taking part in exploration works in other countries. Proof of growth are the monographs issued; the large number of scientific and popular articles; the defended $17 \mathrm{PhD}$ and four DSc theses; the new, found in Bulgaria, minerals, rocks, deposits and occurrences of ore and non-metallic raw materials with different applications.

This overview examines in a detailed way the different directions in researches on metasomatic processes in Bulgaria: geochemical, mineralogical-petrological, structural-tectonic, theoretical and experimental modelling. The most important scientific and applied contributions are noted, and the problems in the study of metasomatic processes are briefly discussed.

Research on metasomatic rocks (especially wall-rock alterations) and results are widely used in the discovery of a number of ore and raw material deposits, as well as in the proper direction of geological exploration and mining in promising areas.

Kunov, A. 2017. Metasomatic studies in Bulgaria - an overview. Geologica Balcanica 46 (2), 32. 